\title{
EFFECTS OF MONETARY - EXCHANGE POLICY TO DEVELOPMENT OF AGRICULTURE COMPETITIVENESS IN THE REPUBLIC OF SERBIA
}

\author{
Professor Radica Pavlović, PhD \\ Faculty for Business Studies, Požarevac, Serbia \\ rpavlovic@megatrend.edu.rs \\ Professor Slobodan Stamenković, PhD \\ Faculty for Business Studies, Požarevac, Serbia, \\ sstamenkovic@megatrend.edu.rs \\ Professor Slobodan Stefanović, PhD \\ Graduate School of Applied Professional Studies, Vranje, Serbia \\ slobodanstef@gmail.com \\ Vladan Vučić, PhD \\ "Jumis" Ltd., Nis, Serbia \\ Vladan.vucic@gmail.com
}

\begin{abstract}
The Republic of Serbia has one of the most important resources - agricultural resources, which are affected by the monetary - exchange policy, and that, as such, is the backbone of Serbia's economic development, which should be based on the exploitation of agricultural land since this resource puts our country in the region with expressed relative, comparative advantages in relation to a large number of countries. The rise in prices of agricultural products in the long period was much slower than the growth in the price level, which is the agricultural activity in the context of primary production was placed in a very disadvantageous position. The active fiscal policy, through excise taxes on petroleum products leads to higher costs in farming than in any other area. Consumption of petroleum products is the biggest expense that directly participate in the production process. Neither in terms of monetary -exchange policy situation is not favorable. The unreal exchange rate policy stimulated imports and discouraged real exports of agricultural product results in the "unrealistic" low productivity in this sector. In this regard, it is important to establish an appropriate economic policy through monetary, fiscal and exchange mechanism, in order to create a competitive advantage of agricultural production in this area.
\end{abstract}

Keywords: monetary - exchange policy, agriculture, development.

\section{Introduction}

Modern business conditions in Republic of Serbia characterizing illiquid and inflationary economic environment [1] calls for a revision of factors and factors of economic development. Agricultural land as a natural resource is the backbone of economic development of the Republic of Serbia. The steady increase in urban and suburban areas, industrial areas, infrastructure and like, on the one hand and inadequate macroeconomic especially monetaryexchange, policy on the other hand, arable agricultural land per capita is decreasing. In this way, reduces the availability of this precious natural resource who is not expandable, nonrenewable and not multiplied, as its rate of capacity utilization [2]. The development of agriculture is a critical contribution to overall economic growth and the increase in agricultural production leads to increased demand for recruitment processing facilities [3], which is creating a basis for the increase in employment, which is of crucial importance if we bear in mind that "since 2009. when it fell by $18.4 \%$, the purchasing power every year fall significantly to be in the first seven months of the 2012 . compared to the same period last year fell by $23.5 \%$ [4]. Agricultural land for the Republic of Serbia is the primary natural resource, which does not mean that the national economy has no other natural resources and their exploitation should be ignored.

Economic development of Serbia should be based on the exploitation of agricultural land since this resource puts our country in areas with high relative, comparative advantages in relation to a large number of countries. The economic development should comprise: primary 
agricultural production (Farming and Animal Husbandry), development of food industry, the development of the chemical industry (fertilizers and plant protection of field crops) and the development of the industry for the production of agricultural machinery. Primary agricultural production is generator of the food industry, chemical industry and for the production of agricultural machinery [5].

Inadequate economic (monetaryexchange and fiscal policy) can not be compensated by any efforts of the company [6]. What was the development of agriculture of Republic of Serbia and what will be, can safely be said, depends only on macroeconomic policy (fiscal and monetary) determined at the national level.

\section{Characteristics and features of economic policy in the Republic of Serbia}

Monetary policy as part of the economic policy aims to ensure price stability, economic growth, full employment and balanced payments balance [7]. In the period of 2001-2012. restrictive monetary policy was guided. The main instrument of prudent restrictive monetary policy was a high rate of required reserves, especially in the foreign assets of commercial banks. High rates of compulsory reserves have caused a lower supply of money in the financial markets and high interest rates on the loans. Primary agricultural production has a large time cycle for the production of finished products (in crop one year) [8]. During this time, farmers made continuous investments in manufacturing, with those who are forced to borrow money from commercial banks, both for current investments in the manufacturing process and for the purchase of agricultural machinery, paying a high price for borrowed money because of the high interest rates of commercial banks. This substantially increases the costs of primary agricultural production [9]. Also, there is a spillover of funds from the banking sector in the economy. While the world economy under the impact of the crisis 'pumping' money into the financial sector, which is by nature accommodating, the interest margins remains real economy and sustainable development [10].

During the period (2001-2012) were implemented policy of overvalued exchange rate against the euro. Cumulative inflation rate in the period 2000-2010 amounted to $252 \%$. In this period, the dinar appreciated steadily against the euro, which has significantly affected the poor competitiveness of our agricultural and food products in the world market. Overvalued dinar favored the import sector is a discouraging effect on exports of domestic products. Stimulating imports was forced the consumption of foreign consumer goods, which are with cheap euro exercised much greater than the actual competition, which led to a decrease in demand for domestic products and declining levels of capacity utilization of domestic producers [11]. Overvalued domestic currency and high interest rates are a recipe for disaster [12]. It is true that the exchange rate is market determined, but this market is heavily manipulated and deformed by the burden of servicing the public debt denominated in foreign currency, far into the future and the market is distorted, and so it came under the influence of strong foreign capital inflows from privatization and other accounts with the resulting appreciation of the dinar is also timed and is separated from the fundamental factors that determine the structure and functioning of the economy and as such it represents a devastating blow for economy [13].

Navigation of the real effective exchange rate is given in table 1. 
Table 1: Trends in the real exchange rate

\begin{tabular}{|c|c|c|c|c|}
\hline Year & $\begin{array}{l}\text { Chain indices } \\
\text { (end of prev. } \\
\text { year }=100)^{14}\end{array}$ & Cumulatuve & $\begin{array}{c}\text { Official exchange } \\
\text { rates } \\
\text { Euro/Din }^{2}\end{array}$ & $\begin{array}{c}\text { Real exchange } \\
\text { Euro/Din }\end{array}$ \\
\hline 2001 & 130,0 & - & 59,7000 & 77,6100 \\
\hline 2002 & 116,8 & 151,84 & 61,5845 & 93,5100 \\
\hline 2003 & 101,9 & 154,72 & 68,4861 & 105,9617 \\
\hline 2004 & 98,9 & 153,02 & 79,0803 & 121,0087 \\
\hline 2005 & 101,6 & 155,47 & 85,5000 & 132,9269 \\
\hline 2006 & 114,2 & 177,55 & 79,0000 & 140,2645 \\
\hline 2007 & 109,7 & 194,77 & 79,2362 & 154,3283 \\
\hline 2008 & 95,1 & 185,23 & 88,6010 & 164,1156 \\
\hline 2009 & 97,7 & 180,97 & 95,8888 & 173,5300 \\
\hline 2010 & 96,9 & 175,36 & 105,4982 & 185,0016 \\
\hline
\end{tabular}

Source: Stamenkovic, S., Pavlovic, R., Pavlovic, M.,«Economic Policy as a Catalys for The Development of Competitive Agricultural Sector and Stimulation of Agricultural Entrepreneurship », International Scientific Conference: "Strengthening the Competitiveness and Economy Bonding of Historical Banat - SCEBB", Proceedings, Megatrend University Belgrade, Vrsac, 28-29 september 2011.

The dinar for ten years cumulatively appreciated $75.36 \%$. In 2004. was slightly depreciated as in the period of 2008-2010. years in which the level of depreciation of much lower intensity level of dinar appreciation. These developments largely explain the state of the national economy.

Table 2: Growth rate in Serbia (in\%)

\begin{tabular}{|c|c|c|c|c|}
\hline \multirow[t]{2}{*}{ Year } & \multicolumn{2}{|c|}{ TOTAL } & \multicolumn{2}{|c|}{$\begin{array}{l}\text { Producers costs of } \\
\text { agricultural products }\end{array}$} \\
\hline & Per year & Cumulative & Per yaer & Cumulative \\
\hline 2003 & 7,8 & & 0,5 & \\
\hline 2004 & 13,7 & 22,57 & 10,2 & 10,75 \\
\hline 2005 & 17,7 & 44,26 & 15,6 & 28,03 \\
\hline 2006 & 6,6 & 53,78 & 9,2 & 39,81 \\
\hline 2007 & 11,0 & 70,70 & 16,9 & 63,43 \\
\hline
\end{tabular}




\begin{tabular}{lcccc}
\hline 2008 & 8,6 & 85,38 & 26,3 & 106,42 \\
\hline 2009 & 6,5 & 97,62 & $-4,9^{[6]}$ & 96,29 \\
\hline 2010 & 10,3 & 117,97 & $29,8^{[7]}$ & 154,79
\end{tabular}

Source: Stamenkovic, S., Pavlovic, R., Pavlovic, M.,«Economic Policy as a Catalys for The Development of Competitive Agricultural Sector and Stimulation of Agricultural Entrepreneurship », International Scientific Conference: "Strengthening the Competitiveness and Economy Bonding of Historical Banat - SCEBB", Proceedings, Megatrend University Belgrade, Vrsac, 28-29 september 2011.

In the period of 2003-2010. cumulative growth rate of agricultural products has a $154.79 \%$, and cumulative growth rate of the general price level is $117,97 \%$. However, until 2008. growth rate in prices of agricultural products was lower than the growth rate of prices which caused the reduction of an agricultural production due to depopulation and reorientation working population in other economic activities. In 2008. agricultural prices record significant growth to in the next year price growth of agricultural product was negative (- 4.9\%). In 2010. growth rate of agricultural products record substantial growth, which resulted to in the cumulative increase in prices of agricultural products is greater than the cumulative increase in the price level (table 2) [16]. However, the actual cause of the high rate of growth of agricultural products is relatively low yields last year, inadequate agricultural policies and high prices on the world market are motivated by exporting agricultural products [17].

As said, the prices of liquid fuels and lubricants, which are the primary input to the primary crop production achieved significantly higher growth than the overall price level (table 3). 
Table 3: Indices rising prices of liquid fuels and chemicals for agriculture

\begin{tabular}{|c|c|c|c|c|}
\hline \multirow[b]{2}{*}{ Year } & \multicolumn{2}{|c|}{ Liquid fuel and lubricants } & \multicolumn{2}{|c|}{ Chemicals for agriculture } \\
\hline & $\begin{array}{l}\text { Chain indices } \\
\text { (Details from the } \\
\text { Republic Bureau of } \\
\text { Statistics) }\end{array}$ & Cumulative & $\begin{array}{l}\text { Chain indices } \\
\\
\text { (Details from the } \\
\text { Republic Bureau of } \\
\text { Statistics) }\end{array}$ & Cumulative \\
\hline 2003 & 104,7 & - & 99,7 & - \\
\hline 2004 & 108,8 & 113,91 & 101,9 & 101,59 \\
\hline 2005 & 124,1 & 141,37 & 94,8 & 96,31 \\
\hline 2006 & 119,1 & 168,37 & 118,8 & 114,42 \\
\hline 2007 & 100,3 & 168,87 & 107,7 & 123,23 \\
\hline 2008 & 113,8 & 192,18 & 101,2 & 124,71 \\
\hline 2009 & 135,3 & 260,02 & $95,4^{[9]}$ & 118,97 \\
\hline 2010 & 122,2 & 317,74 & $105,4^{[10]}$ & 125,39 \\
\hline
\end{tabular}

Source: Stamenkovic, S., Pavlovic, R., Pavlovic, M.„«Economic Policy as a Catalys for The Development of Competitive Agricultural Sector and Stimulation of Agricultural Entrepreneurship », International Scientific Conference: "Strengthening the Competitiveness and Economy Bonding of Historical Banat - SCEBB", Proceedings, Megatrend University Belgrade, Vrsac, 28-29 september 2011.

The cumulative increase in prices of liquid fuels in the observed period amounted to $317.74 \%$, which is significantly higher than the growth in the price level $(117.97 \%)$. The rise in prices of liquid fuels is especially pronounced in 2009 (35.3\%) and 2010 $(22.2 \%)$. Uptrend price of liquid fuels conditioned by the increase in oil prices on the world market and the excise policy, which is more intense in recent years [18]. Rising prices of chemicals for agriculture is slightly above the general level of price increase and the impact of this aspect of the growth rate of this category of products is neutral.

\section{The effects of monetary - exchange policy on agriculture}

Monetary policy and exchange rate policy is a depressing influence on the development of the agricultural sector, considering that for Serbia is of great importance development of primary agricultural production of the most significant natural resources that should be the basis for the development of the food industry and other related industrial activities [19]. It should be noted that the fiscal and custom policy is not to the advantage of determining favorable conditions for the development of the agricultural sector. Liquid fuels excise policy had a significant price increase, much faster than the general price level. Bearing in mind that in agricultural production (crop) the cost of liquid fuels is an important item in the cost of agricultural products, the excise policy has an adverse impact on the profitability of this business activity.

Observed by sector agriculture is with manufacturing one of the pillars of regional development [20] of Serbia. Agricultural production in Serbia is stagnating. The main cause of this situation in agricultural production in this area lies in macroeconomic policy, and largely in monetary exchange policy, which had resulted in insufficient economic development in general, and thus the development of agricultural production. Yields of crops recorded fluctuations from year to year, which indicates that the volume of agricultural production, for example husbandry depends entirely on the 
weather. This points to the fact that there was no adequate agricultural policy. Since the Serbian agricultural land has to be one of the main natural resources, it was necessary to build the infrastructure of irrigation systems and provide a stable higher yields that would substantially less dependent on weather conditions throughout the year.

Economic subjects, agricultural producers and regional institutions of the Republic of Serbia can not significantly affect the extent monetary exchange policy and the factors that regulate economic development. However, better organization (eg, formation of cooperatives) can be partially mitigated the negative effects of monetary exchange and macroeconomic policy in general. Can be achieved by better marketing of agricultural products, which involves avoiding intermediaries in the transport process and in direct contact with customers achieving better prices for agricultural products, more favorable conditions in procurement of raw materials, which directly bring down production costs.

Having noted the insight necessary to adopt urgent measures to get out of the vicious circle and the first revival of agricultural activities and then to raise the competitiveness of [21], where the special role should have the National Bank of Serbia and the application of appropriate incentive measures and instruments of monetary policy, which would go towards the restoration of economic activities through the development of agriculture as a strategic resource and competitive advantage, increasing employment, reducing inflation and rising the competitiveness of agricultural products.

\section{Conclusion}

The development of agriculture in general, and especially in regions where agricultural resources are the dominant natural source, should be a priority in order to design and implement macroeconomic policies. New tendencies in the world indicate a steady growth in demand for food, and the possibilities for increasing the volume of food production are diminishing. The resources for food production are limited, what more agricultural land in the world are reducing. We should not ignore the fact that climate change and global warming is negatively affecting the volume of food production in the world. All this suggests that in the future food will be a strategic resource.

As the Republic of Serbia is one of the most productive regions in Europe, it is logical to conclude, in accordance with the above facts, it is an attractive area and strategic location for the development of agriculture, and therefore the food industry. These facts indicates that Serbia should look for opportunities for the development of the above activities, along with the wonderful support of the state in this direction with their development programs, financial resources and adequate macroeconomic policy. Therefore, monetary exchange and the entire economic policy appears as a catalyst for the development and competitiveness of the agricultural sector and by stimulating agricultural entrepreneurship in Serbia, and is free to conclude that monetary - exchange policy did not achieve economic goals.

\section{REFERENCES}

1. Bogavac - Cvetković N., Pavlović R., Stamenković S., Stefanović S., (2013) Liqudity analyses as the function of improvement of company activities in the menagment aspect,Metalurgia international, No 3, Romania.

2. Pavlović, R., Pavlović, M., Stamenković, S. (2012) Stamenković, M., Capacity Analysis of Agricultural land use as a natural resources, $2^{\text {nd }}$ International Sympousium of Natural Resources Management, Proceedings, Faculty of Management Zajecar, May, p.p. $175-183$.

3. Båge, L, et al (2006) Agriculture and Economic Development, The magazine of the United Nations Environment Programme, Special Edition, UNEP and the International Bank of Reconstruction and Development/World Bank.

4. Pavlović, M., Stamenković, S. (2012) Creating Role of Unions in Ambient Conditions for Increasing Employment, The 4th International Scientific Conference: TRADE UNIONS AND POLITICS, Proceedings, Higer Education Institution for applied studies for Entrepreneurialship, Belgrade, November, p.88.

5. Stamenković, S., Pavlović, R., Pavlović, M. (2011) Economic Policy as a Catalys for The Development of Competitive Agricultural Sector and Stimulation of Agricultural Entrepreneurship , International Scientific Conference: "Strengthening the Competitiveness and Economy Bonding of Historical Banat - SCEBB", Proceedings, Megatrend 
University Belgrade, Vršac, 28-29 september, p.p. 127-133.

6. Kovač, O. (2006) Konkurentnost i politika deviznog kursa u Srbiji, Megatrend revija, vol. 3, br. 1, str. 5 .

7. Krstić, B. (2001) Bankarstvo, Ekonomski fakultet, Niš, str. 48.

8. Pavlović, R., Pavlović, M., Stamenković, S., Stamenković, M. (2012) Financial-Accounting Indicators of Companies The Condition of The Transition Stagflation», The 3rd International Scientific Conference: Capitalism in Transition, Proceedings, Higer Education Institution for applied studies for Entrepreneurialship, Belgrade, June 2012., p.p. 337-343.

9. Stamenković, S., Pavlovic, R., Pavlović, M (2011) Op.cit.

10. Anufijeb, A., Dašić, G. (2011) Agrar kao spas za posrnulu ekonomiju Srbije, Ecologica, vol. 18, br. 62, str. 255

11. Stamenković, S., Pavlovic, R., Pavlović, M. (2011) Op.cit.

12. Stiglic, D.E. (2001) Zamke prebrze privatizacije intervju. Politika, Beograd, 15. 10.
13. Madžar, LJ. (2005) Voznesenje dinara, Ekonomska misao, vol. 38, br. 3-4, str. 115.

14. Statistički bilten, Narodna Banka Srbije, 2010.

15. Kursna lista, Narodna Banka Srbije: http://www.nbs.rs/internet/cirilica/scripts/ondate.html

16. Stamenković, S., Pavlovic, R., Pavlović, M. (2011) Op.cit.

17. Izveštaj o inflaciji, maj, 2011, Narodna banka Srbije;

18. Pavlović, R., Pavlović, M., Stamenković, S., Accounting Ratios Financial Situation Companies in Serbia-Situation and Tendencies, Scientific Journal: Entrepreneurship, Higher Educational Institution for applied studies for Entrepreneurship : Centre for Industrial Relations Vol.1, No. 1/2012, Belgrade, 2012., p.p. 43-59

19. Stamenković, S., Pavlovic, R., Pavlović, M. (2011) Op.cit.

20. Cvetković- Bogavac, N. (2011) Entrepreneurial Ambience of Historical Banat - Current Situation and Development Perspectives, International 